\author{
Roland Podlewski ${ }^{1}$ \\ Włodzimierz Płotek ${ }^{1}$ \\ Małgorzata Grześkowiak ${ }^{1}$ \\ Tomasz Małkiewicz ${ }^{1}$ \\ Krystyna Frydrysiak ${ }^{2}$ \\ Zbigniew Żaba ${ }^{1}$
}

\title{
CARBON DIOXIDE AS A POTENTIAL DANGER TO MEDICAL RESCUE TEAMS AT WORK - A CASE STUDY
}

\author{
DWUTLENEK WĘGLA JAKO POTENCJALNE ZAGROŻENIE \\ W PRACY ZESPOŁÓW RATOWNICTWA MEDYCZNEGO - OPIS PRZYPADKU
}

\footnotetext{
${ }^{1}$ Poznan University of Medical Sciences / Uniwersytet Medyczny im. Karola Marcinkowskiego w Poznaniu, Poznań, Poland

Department of Teaching Anesthesiology and Intensive Therapy / Zakład Dydaktyki Anestezjologii i Intensywnej Terapii

${ }^{2}$ Medical University of Lodz / Uniwersytet Medyczny w Łodzi, Łódź, Poland

Department of Emergency Medicine and Disaster Medicine / Zakład Medycyny Ratunkowej i Medycyny Katastrof
}

\begin{abstract}
Medical rescue teams might be exposed to the risk of accidental poisoning while performing rescue procedures. Exposure to the risk of lethal carbon dioxide $\left(\mathrm{CO}_{2}\right)$ concentrations is a rare situation. This case study describes rescuing a patient who suffered from sudden cardiac arrest due to accidental $\mathrm{CO}_{2}$ poisoning. The victim was finally evacuated and resuscitated, but the circumstances of the rescue operation point to the need to equip ambulances with carbon dioxide detectors and hermetic oxygen masks. Med Pr 2017;68(1):135-138
\end{abstract}

Key words: environmental exposure, carbon dioxide, cardiopulmonary resuscitation, medical rescuer, gas poisoning, grain dryer

\begin{abstract}
STRESZCZENIE
Zespoły ratownictwa medycznego mogą być narażone na ryzyko przypadkowych zatruć w trakcie wykonywania medycznych czynności ratunkowych. Do rzadkich sytuacji należy narażenie na śmiertelne stężenie dwutlenku węgla $\left(\mathrm{CO}_{2}\right)$. W pracy opisano akcję ratunkową pacjenta, u którego doszło do nagłego zatrzymania krążenia z powodu przypadkowego zatrucia $\mathrm{CO}_{2}$. Ostatecznie udało się poszkodowanego ewakuować i zreanimować, ale okoliczności towarzyszące tej akcji sugerują konieczność wyposażenia karetek zespołów ratownictwa medycznego w detektory tlenku i dwutlenku węgla oraz szczelne maski tlenowe. Med. Pr. 2017;68(1):135-138

Słowa kluczowe: ekspozycja środowiskowa, dwutlenek węgla, resuscytacja krążeniowo-oddechowa, ratownik medyczny, zatrucie gazem, suszarnia zboża

Corresponding author / Autor do korespondencji: Roland Podlewski, Poznan University of Medical Sciences, Department of Teaching Anesthesiology and Intensive Therapy, Marii Magdaleny 14, 61-861 Poznań, Poland, e-mail: rpodlew@ump.edu.pl

Received: November 25, 2015, accepted: October 18, 2016
\end{abstract}

\section{INTRODUCTION}

Carbon dioxide $\left(\mathrm{CO}_{2}\right)$ is a colorless, odorless and nonflammable gas, soluble in water, with a molecular weight of $44 \mathrm{Da}$ and density of $1.977 \mathrm{~g} / \mathrm{dm}^{3}\left(0^{\circ} \mathrm{C}, 1013 \mathrm{hPa}\right)$. In the surrounding environment $\mathrm{CO}_{2}$ is a product of combustion and fermentation of organic matter.

The $\mathrm{CO}_{2}$ content in fresh air (averaged between sealevel and $10 \mathrm{kPa}$ level, i.e., about the altitude of $30 \mathrm{~km}$ ) varies between $0.036-0.039 \%$ (360-390 ppm), depend- ing on the location. The $\mathrm{CO}_{2}$ concentration is higher in mines, sugar refineries, distilleries, grain silos and drains. Carbon dioxide is an asphyxiant gas and not classified as toxic or harmful in accordance with the Globally Harmonized System of Classification and Labelling of Chemicals Standards of the United Nations Economic Commission for Europe within the meaning of the Organisation for Economic Co-operation and Development (OECD) Guidelines for the Testing of Chemicals. The maximum admissible concentra- 
tion (MAC) for $\mathrm{CO}_{2}$ and the short term exposure limit (STEL) are $9000 \mathrm{mg} / \mathrm{m}^{3}$ and $27000 \mathrm{mg} / \mathrm{m}^{3}$, respectively. The MAC for CO and the STEL are $23 \mathrm{mg} / \mathrm{m}^{3}$ and $117 \mathrm{mg} / \mathrm{m}^{3}$, respectively.

The occupational exposure is very common in factories: in metallurgy, welding, production of fire extinguishers. Employers working in coolers and with dry ice, during production of carbonated water and in medicine - during preparation of carbonic acid bath are also at risk of intoxication.

The symptoms and signs of $\mathrm{CO}_{2}$ intoxication are primarily neurological. Poisoning with carbon dioxide is usually a combination of life-threatening hypoxia and hypercapnia, which leads to impairment in the level of consciousness ranging from drowsiness and confusion to even deep coma and respiratory acidosis. Intense hypercapnia may lead to cerebral edema and paralysis of the respiratory center. In concentrations of up to $1 \%$, it will make some people feel drowsy. When breathing the air containing $\mathrm{CO}_{2}$ at concentrations exceeding $5 \%$, the gas causes shortness of breath, anxiety and stimulation of the respiratory center. Concentrations of $7-10 \%$ may cause dizziness, headache, visual and hearing dysfunction, and unconsciousness within a few minutes to an hour. Concentrations exceeding $10 \%$ cause hallucinations and impaired consciousness, including coma and convulsions. Concentrations of more than $20 \%$ cause death within several minutes whereas concentrations exceeding 30\% cause instantaneous death.

The most frequent motor signs are muscle twitching and fine tremors of the extremities or face. Myoclonus and generalized convulsions may be observed. Reflex action changes. The intracranial pressure increases. The non-neurologic symptoms and signs of $\mathrm{CO}_{2}$ intoxication are also cardiopulmonary. The initial period of hypertension goes to hypotension and shock. Tachycardia is very frequent.

Carbon dioxide poisonings have been described in the world literature since the 1950s [1-3]. These were usually accidental poisonings, where $\mathrm{CO}_{2}$ had come from dry ice [4,5], a fermentation tank [6], liquid carbon dioxide that had been unintentionally opened [7], a tank containing sludge made of wine and activated charcoal [8], inspection of a concrete well [9]. There have also been cases of $\mathrm{CO}_{2}$ poisonings due to suicidal attempts or even murders, where $\mathrm{CO}_{2}$ had come from dry ice $[10,11]$ or $\mathrm{CO}_{2}$ cylinders [12].

Carbon dioxide poisonings require immediate first aid and calling medical emergency system services. In Poland the system of the State Emergency Medical Servic- es (EMS) was established in 2006 and it consists of hospital emergency departments (ED) and medical rescue teams, including basic (B) and specialist (S) rescue teams, with air rescue teams. Medical rescue teams provide their services only to patients who are in a state of emergency health hazard and outside hospital. In 2015 there were 1460 medical rescue teams in Poland [13].

Carbon dioxide poisonings represent a medical and organizational challenge to medical rescue teams. Below there is a case study of a victim who suffered from cardiac arrest due to $\mathrm{CO}_{2}$ poisoning.

\section{CASE REPORT}

At 8:47 a.m. a $S$ medical rescue team was sent by a dispatcher to an unconscious 54-year-old man who had been repairing machinery in a grain silo (a maize warehouse) (Photo 1). In this case $\mathrm{CO}_{2}$ was elevated as a result of fermentation of seed corn in a grain silo. According to the information reported to the dis-patcher, the man suffered from an epileptic seizure.

The medical rescue team arrived at the place after $11 \mathrm{~min}$. There were $3 \mathrm{men}$ in the rescue team who arrived in a $S$ ambulance: a doctor (D), paramedic/ driver (P-1) and paramedic (P-2). Immediately did they start rescuing the patient. None of the witnesses of the event gave first aid to the patient. The D and P-2 went to the rescue zone. They climbed a ladder about $3 \mathrm{~m}$ down into a room that was $6 \mathrm{~m}$ long, $2.2 \mathrm{~m}$ wide and $2.6 \mathrm{~m}$ deep, where the patient was. After they had taken a few breaths, both of them felt sudden weakness, vertigo and nausea. They left the room and the patient inside. The P-1 called a fire brigade and informed them of the possible danger and problems of the other members

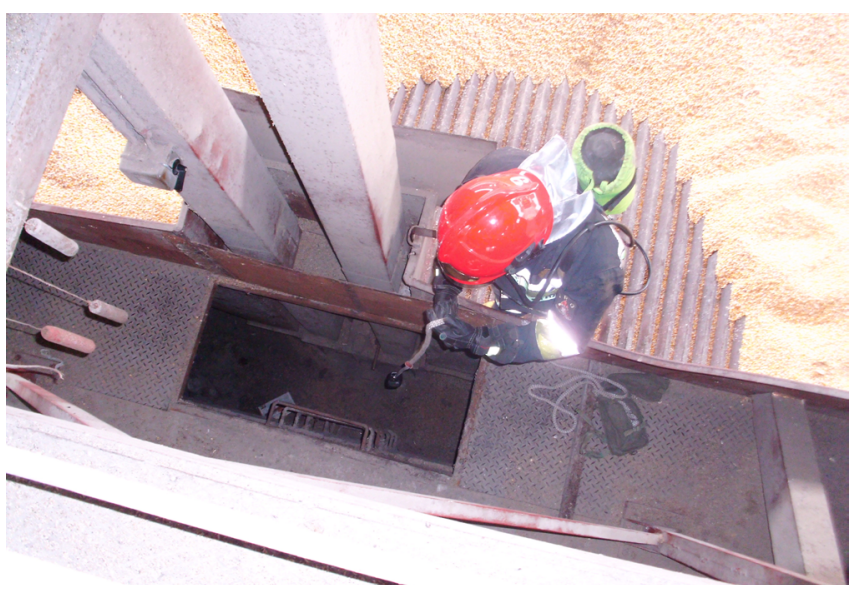

Photo 1. Technological shaft in a grain dryer

Fot. 1. Szyb technologiczny suszarni zboża 
of the $\mathrm{S}$ crew. In the meantime the P-2 returned to the ambulance and put on an oxygen mask without an oxygen reservoir (the flow rate at $12 \mathrm{l} / \mathrm{min}$ ) for about $20 \mathrm{~s}$ and returned to the patient. Meanwhile the $\mathrm{D}$ held his breath, went down to the patient again and pulled him near the ladder. The P-1 took a spine board and belts, held his breath and climbed down the ladder to the patient. He used the belts to tie a knot and he returned outside.

The D and P-1 pulled the patient out of the room together and implemented the ABCDE scheme (Airway, Breathing, Circulation, Disability, Exposure Scheme). They confirmed cardiac arrest and diagnosed asystole. The patient received cardiopulmonary resuscitation (CPR) according to the European Resuscitation Council (ERC) guidelines 2010 [14]. The patient was being resuscitated for $40 \mathrm{~min}$ after he had been evacuated from the room. Asystole continued for $36 \mathrm{~min}$. It was followed by pulseless electrical activity and finally the patient recovered ventricular rhythm with pulse. During the CPR the patient was administered $9 \mathrm{mg}$ adrenaline intravenous (i.v.), $500 \mathrm{ml} 0.9 \%$ sodium chloride $(\mathrm{NaCl})$ i.v. and $40 \mathrm{mmol} 8.4 \%$ sodium bicarbonate i.v. The patient had his trachea intubated 2 min after he had been evacuated from the room. The firefighters helped to resuscitate the patient.

After the return of spontaneous circulation the patient was transported in the $S$ ambulance to the emergency department in a district hospital. The medical rescuers had temporary weakness, vertigo and nausea in a grain silo. Thereafter they felt well. While being transported, the patient was being ventilated with $100 \%$ oxygen. In the emergency department the patient attempted to remove the endotracheal tube. After a few minutes the patient was transferred to the care of an anaesthesiologist on duty and he was transported to the Department of Anaesthesiology and Intensive Care (DAIC).

After neurological consultation in hospital the patient was assessed as 15 points in terms of the Glasgow Coma Scale (GCS), there was a lack of any neurological deficiency. During hospitalization the patient's circulation was stable and the patient did not require any catecholamines. Upon admission to the DAIC the patient's state was as pictured in the Table 1 . The patient was treated at the DAIC for several days and he was discharged from hospital without any neurological damage.

The fire brigade measured the $\mathrm{O}_{2}$ concentration in the room $-16 \%$. The name of apparatus used by the fire brigade to determine the $\mathrm{O}_{2}$ concentration is MultiPro (Sperian, USA). The MultiPro may be configured to simultaneously monitor oxygen, carbon monoxide,
Table 1. Laboratory tests of the patient who suffered from sudden cardiac arrest due to accidental $\mathrm{CO}_{2}$ poisoning, upon admission to the Department of Anaesthesiology and Intensive Care (DAIC)

Tabela 1. Badania laboratoryjne pacjenta, u którego doszło do nagłego zatrzymania krążenia $\mathrm{z}$ powodu przypadkowego zatrucia $\mathrm{CO}_{2}$, wykonane po przyjęciu na Oddział Anestezjologii i Intensywnej Terapii (OAiIT)

\begin{tabular}{|c|c|}
\hline $\begin{array}{l}\text { Laboratory tests } \\
\text { Badania laboratoryjne }\end{array}$ & $\begin{array}{l}\text { Patient's blood } \\
\text { Krew pacjenta }\end{array}$ \\
\hline Arterial $\mathrm{pH} / \mathrm{pH}$ tętnicze & 7.105 \\
\hline $\begin{array}{l}\text { Arterial partial pressure of carbon dioxide / Prężność } \\
\text { dwutlenku węgla we krwi tętniczej }\left(\mathrm{pCO}_{2}\right)[\mathrm{mm} \mathrm{Hg}]\end{array}$ & 40.5 \\
\hline $\begin{array}{l}\text { Arterial partial pressure of oxygen / Prężność tlenu } \\
\text { we krwi tętniczej }\left(\mathrm{pO}_{2}\right)[\mathrm{mm} \mathrm{Hg}]\end{array}$ & 169.6 \\
\hline Bicarbonate ion / Wodorowęglany $\left(\mathrm{HCO}_{3}\right)[\mathrm{mmol} / \mathrm{l}]$ & 15 \\
\hline Base excess / Nadmiar zasad (BE) & -10.2 \\
\hline Urea / Mocznik [mg/dl] & 16.3 \\
\hline Sodium / Sód [mmol/l] & 138.2 \\
\hline Potassium / Potas [mmol/1] & 3.29 \\
\hline Creatinine / Kreatynina [mg/dl] & 0.91 \\
\hline Calcium / Wapń [mmol/1] & 4.65 \\
\hline $\begin{array}{l}\text { Alanine aminotransferase / Aminotransferaza } \\
\text { alaninowa (ALAT) [IU/l] }\end{array}$ & 71 \\
\hline $\begin{array}{l}\text { Aspartate aminotransferase / Aminotransferaza } \\
\text { asparaginowa (AspAT) [IU/l] }\end{array}$ & 234 \\
\hline Total protein / Białko całkowite $[\mathrm{g} / \mathrm{dl}]$ & 6.9 \\
\hline Glucose / Glukoza [mg/dl] & 228 \\
\hline C-reactive protein / Białko C-reaktywne $[\mathrm{mg} / \mathrm{l}]$ & 2 \\
\hline Haemoglobin / Hemoglobina [g/dl] & 12.2 \\
\hline Hematocrit / Hematokryt [\%] & 0.36 \\
\hline Red blood cells / Erytrocyty $\left[10^{6} / \mu \mathrm{l}\right]$ & 3.34 \\
\hline $\begin{array}{l}\text { Mean corpuscular volume / Wskaźnik średniej } \\
\text { objętości krwinki czerwonej [fl] }\end{array}$ & 109.1 \\
\hline White blood cells / Leukocyty $\left[10^{3} / \mu \mathrm{l}\right]$ & 6.18 \\
\hline Platelets / Płytki krwi $\left[10^{3} / \mu \mathrm{l}\right]$ & 160 \\
\hline
\end{tabular}

hydrogen sulfide and combustible gases and vapors. The MultiPro uses electrochemical toxic gas sensors. In the other countries the fire brigades are also equipped with the same apparatus MultiPro and additionally the others e.g., Dräger X-am 5600 (Drägerwerk AG \& Co. KGaA, Germany), Measurement System Analysis (MSA) multi detector (MSA, USA). In Poland the medical rescue teams are not equipped with hermetic oxygen masks. In the other countries the fire brigades are equipped with such pieces of equipment. 


\section{CONCLUSIONS}

The study has presented the case of $\mathrm{CO}_{2}$ poisoning complicated by sudden cardiac arrest. It is an interesting presentation concerning possible hazards to medical rescue teams. Thanks to the dedication of the emergency services the patient was successfully resuscitated. Nevertheless, it involved the exposure of the rescue team to the risk of $\mathrm{CO}_{2}$ poisoning. Medical rescue teams are not equipped with hermetic oxygen masks, which would isolate the rescuers from the toxic environment. It is noteworthy that medical rescue teams and firefighters do not arrive at the scene of an accident at the same time. Thus, there is the increased risk of exposure of the rescue team to harmful factors which are difficult to detect (in this case $-\mathrm{CO}_{2}$ ). Due to the fact that waiting even for a short time for the victim to be evacuated from the zone of exposure to toxic gases may be decisive to the victim's survival, it is recommended that the issue of additional rescue equipment in ambulances should be taken into consideration.

The conclusion is that medical rescue teams should be equipped with $\mathrm{CO}_{2}$ detectors and hermetic oxygen masks.

Accidental $\mathrm{CO}_{2}$ poisoning may be a reversible cause of cardiac arrest. The case study presents the hazard to medical rescue teams and firefighters. Equipping medical rescue teams with toxic gas detectors should be taken into consideration.

\section{REFERENCES}

1. Walter AL. Case report: Carbon dioxide intoxication; exposure to dry ice. Mo Med. 1957;54(5):436.

2. Johnston RF. The syndrome of carbon dioxide intoxication: Its etiology, diagnosis, and treatment. Med Bull (Ann Arbor). 1959;25:280-92.

3. O'Reilly RJ. The clinical recognition of carbon dioxide intoxication. Dis Chest. 1960;37:185-92, https://doi.org/ 10.1378/chest.37.2.185.
4. Jacobs DE, Smith MS. Exposure to carbon dioxide in the poultry processing industry. Am Ind Hyg Assoc J. 1988; 49(12):624-29, https://doi.org/10.1080/15298668891380358.

5. Yamazaki M, Islam MN, Ogura Y, Honda K, Tsuchihashi H, Nishioka H. An autopsy case of carbon dioxide intoxication. Nihon Hoigaku Zasshi. 1997;51:446-51.

6. Kettner M, Ramsthaler F, Juhnke C, Bux R, Schmidt P. A fatal case of $\mathrm{CO}_{2}$ intoxication in a fermentation tank. J Forensic Sci. 2013;58:556-8, https://doi.org/10. 1111/1556-4029.12058.

7. Halpern P, Raskin Y, Sorkine P, Oganezov A. Exposure to extremely high concentrations of carbon dioxide: A clinical description of a mass casualty incident. Ann Emerg Med. 2004;43:196-9, https://doi.org/10.1016/ j.annemergmed.2003.08.003.

8. Guillemin MP, Horisberger B. Fatal intoxication due to an unexpected presence of carbon dioxide. Ann Occup Hyg. 1994;38:951-7, https://doi.org/10.1093/annhyg/38.6.951.

9. Romeo L, Prigioni P, Marcheselli S, Marchiori L, Cerpelloni M, Fiorini C, et al. [Acute poisoning with carbon dioxide: Report of 2 fatal cases]. Med Lav. 2002;93:26-33. Italian.

10. Rupp W-R, Thierauf A, Nadjem H, Vogt S. Suicide by carbon dioxide. Forensic Sci Int. 2013;231:e30-2, https:// doi.org/10.1016/j.forsciint.2013.05.013.

11. Srisont S, Chirachariyavej T, Peonim AVMV. A carbon dioxide fatality from dry ice. J Forensic Sci. 2009;54: 961-2, https://doi.org/10.1111/j.1556-4029.2009.01057.x.

12. Sautter J, Gapert R, Tsokos M, Oesterhelweg L. Murder-suicide by carbon dioxide $\left(\mathrm{CO}_{2}\right)$ poisoning: A family case from Berlin, Germany. Forensic Sci Med Pathol. 2014; 10:97-102, https://doi.org/10.1007/s12024-013-9495-6.

13. Ministry of Health [Internet]. Warszawa: The Ministry [cited 2015 Nov 15]. [Emergency medical teams]. Available from: http://www.mz.gov.pl/system-ochronyzdrowia/panstwowe-ratownictwo-medyczne/zespolyratownictwa-medycznego. Polish.

14. Nikolaou NI, Arntz HR, Bellou A, Beygui F, Bossaert LL, Caroiu A. European Resuscitation Council Guidelines for resuscitation 2015. Resuscitation. 2015;95:1-80.

This work is available in Open Access model and licensed under a Creative Commons Attribution-NonCommercial 3.0 Poland License / Ten utwór jest dostępny w modelu open access na licencji Creative Commons Uznanie autorstwa - Użycie niekomercyjne 3.0 Polska - http://creativecommons.org/ licenses/by-nc/3.0/pl/deed.en. 